\title{
Overall budget management in construction engineering budget
}

\section{management}

\author{
LI Jianxin \\ Sichuan College of Architecture Technology, Deyang City, SichuanProvince, 618000,China \\ Email: lijianxin8112@126.com
}

\begin{abstract}
Keywords: building engineering; comprehensive budget management; key point; construction industry; financial management

Abstract: Comprehensive budget management is refers to the use of budget of enterprise internal departments and units involved a variety of financial and non-financial resources allocation, assessment, control, easy and effective for the production and operation activities of the enterprise organization and coordination, and then complete the stated objectives of the operation system of management system. By analyzing the main characteristics of the construction industry in our country, and the key points of comprehensive budget management and application are discussed.
\end{abstract}

\section{Introduction}

The so-called comprehensive budget management is refers to the use of budget of enterprise internal departments and units involved a variety of financial and non-financial resources allocation, assessment, control, facilitate effective enterprise organization and coordination of production and operating activities, and then complete the established business objectives of system management. In the construction industry through the application of comprehensive budget management in order to strengthen the construction project investment cost control, and finally achieve the goal of construction enterprises in the completion of the goal to get more benefits.

\section{The main characteristics of the construction industry in China}

\section{Main form of enterprise}

According to the market economic system of our country, we can see that the number present in the form of enterprise in the construction industry of our country, although the construction enterprises have different characteristics, but their scope is relatively single. Most of the construction enterprises of our country state-owned enterprises or state-owned holding enterprises, a few private enterprises, and private construction enterprises in the construction output and market share almost no influence. In the construction industry in China's construction enterprises involved in the business scope is smaller and the single, such as housing construction and civil engineering, cost of construction field covers a very small, under the market economic system reform, prompting the construction enterprises of our country to develop in the direction of diversification[1].

\section{Organization multi polarization}

At present, China's construction industry in the form of organizational institutions tend to multi polarization and the development of the form of matrix. And more of our country construction enterprise organizational structure, these multiple levels of the organization to the construction industry process in the presence of certain differences in the application of comprehensive budget 
management practice, the general use of the matrix type organizational form of application in the field of construction industry. In construction project management department, usually used is staff of project manager to oversee the at the same time to enterprise's functional departments related to the leadership of supervisor is responsible for dual leadership, promotion of multi-level organization.

\section{Extensive management mode}

According to the current data analysis, it is not difficult to see that the construction industry in our country is the most extensive management mode, and in the construction market, the proportion is low. In addition to some large construction enterprises in our country the management of other construction enterprises are using extensive management. And after investment projects, investors in order to be able to quickly receive returns, blindly made building engineering construction to speed up the progress, but some of the construction process to ensure the quality of shorter time is unable to complete the, in order to achieve progress standards have to process is simplified, which appeared in the heavy schedule light quality phenomenon, ignoring the quality of construction.

\section{key points of comprehensive budget management in construction project budget management}

\section{establishment of goal}

Construction enterprises in the development of the budget, to effectively reflect the strategic objectives of the enterprise. But in the establishment of the budget target, high-level enterprises in order to faster to enable enterprises to achieve strategic objectives, the more will the austerity budget, the budget while to achieve the strategic target, the more favorable, but virtually will frustrate the enthusiasm of the staff; grassroots departments of enterprises in order to achieve their performance goals as soon as possible, the general use of strategic target and the enterprise instead of loose budget. Different levels of the establishment of the budget targets in different ways, from the overall construction of the strategic objectives of the strategic objectives of the phenomenon of chaos. So the construction enterprises in the development of budget targets to set a unified standard, both to meet the requirements of competition, but also to meet the objective reality[2].

\section{strengthen the dynamic and comprehensive budget management}

Under the current dynamic market environment model, the construction enterprises should abandon the old static budget management mode and apply the dynamic comprehensive budget management to adapt to the new market environment. The so-called dynamic comprehensive budget management refers to the construction enterprise according to its own operating conditions and the market environment of the objective of the budget management model has been established for the appropriate adjustments. The first thing to do is to the construction enterprise according to the relevant laws and regulations related to budget management objectives and specific tasks set; secondly to consider the possible budget problems, to solve these problems for the corresponding buffer time, to ensure the construction project and can well adapt to the change of market economy, in the process of project implementation there are enough funds, avoid and stop the construction project, the construction of facilities and affect the progress because of irrational allocation of resources; finally, if the change of market environment too fast resulting in budget management can not accord with the current actual situation, so the construction enterprise according to the specific circumstances of the market after the change of budget management in a timely manner, to ensure that in the enterprise of resource consumption within the expected range, reduce enterprise income 
consumption, to achieve optimal benefits of the enterprise.

\section{adopt a reasonable budget}

The overall budget for the construction of the preparation of the need to use up to down and from the bottom to the combination of methods[3]. (1) the total target of enterprise construction enterprise executives and departments object and was put forward; (2) basic units of enterprises according to their own situation to develop reasonable budget for the unit, and submitted to the reported to the Department; (3) division on the basis of the data for the preparation unit presenting the draft budget the Department, and submit to the budget committee, the budget committee according to the draft budget for each department of enterprises overall budget preparation; (4) the budget committee will return to the preparation of the draft budget departments to solicit the views of various departments; (5) the budget for leadership in business analysis and see no problem, identified as the official budget, and then by the executive department one by one. Enterprises to adopt the communicate with each other as the budgeting process, not only the staff's subjective initiative can play an effective, also can make budget targets are implemented, play a role in promoting the implementation of the comprehensive budget management in the construction project budget management.

\section{The application of the comprehensive budget management in the construction project budget management construction companies in the construction industry have been optimized}

At present, China's construction enterprises are mostly state-owned enterprises, the implementation is the cause of the preparation of enterprise management, organization form, in the personnel system of construction enterprises to implement is one of the pyramid model. Such a model for the management and application of high technology index, also enables enterprises to expand business space within the maximum range. On the market of industry construction in our country at present, the overall implementation of the comprehensive budget management, there are still some problems, so in the use of comprehensive budget management in the process can be obtained by employing or set up professional organizations, on the construction of the implementation process in some sectors and technology training. In order to save time and cost, to achieve the purpose of improving the overall efficiency of the enterprise, so that the operation of the construction project to achieve a multiplier effect. For the better part of its management ability construction company, through personnel selection and content of enterprise, outstanding talent concentrated and the establishment of professional organizations on the implementation of the construction project of the design of comprehensive budget management, the formulation and implementation.

\section{establishment of a comprehensive budget management organization}

According to the characteristics of construction enterprises in the use of comprehensive budget management to establish a suitable for the enterprise's budget organization. To the process of construction of institutional constraints and and method of the management system in the construction process of in-depth analysis and research, and according to the problems using the corresponding measures and means, to supervise the implementation of budget management of construction enterprises and implementation.

establish and improve the comprehensive budget management system in the construction industry

For construction enterprises in the comprehensive budget management is carried out, according to 
the comprehensive budget management involves three aspects, namely business budget, financial budget, expenditure budget were a comprehensive analysis, the general operating budget will involve the construction industry enterprises in the income, cost and business level; financial budget include the collection and use of the relevant funds in the construction project; the expenditure budget includes the purchase cost and capital investment budget of the fixed equipment. Establish and improve the comprehensive budget management system in the construction industry to better prepare for the realization of the strategic objectives of enterprises.

\section{correctly deal with the use of a comprehensive budget management problems may arise}

In the implementation of a comprehensive budget management process, all walks of life there is a common misunderstanding, that is, a comprehensive budget management tasks designed to belong to the financial sector, in fact, otherwise. Especially in the construction industry is particularly evident in the comprehensive budget management in the construction enterprise as a comprehensive, integrated management system for the operation of the. In reflecting the seriousness of the system at the same time also according to the practical situation of the flexible use to harvest efficiency of enterprises, the purpose of optimization of interest needs between the various departments coordination, construction enterprises in the implementation of the comprehensive budget management will not only contain the financial operation of the Department of the work, the investment of construction enterprise project cost management and culture construction of contents are included in the, so the application of comprehensive budget management to in building enterprise obtained good results, the need for cooperation between enterprises of various departments.

\section{Conclusion}

To sum up, the construction industry has become a part of an integral part of China's social development process, and the comprehensive budget management as the construction industry is becoming more and more important factors has become budget management in construction enterprises has practical utility management tool and means, the implementation of comprehensive budget management in construction enterprises, to improve the efficiency of enterprises and strategic target has practical significance.

\section{Reference}

[1] Wang Bin. The overall cost management in construction enterprises[J]. Cooperation of economy and technology, 2009 (11).

[2] Chen Lingzhang. Comprehensive budget management in highway construction enterprises[J]. Construction and design, 2006(1).

[3] Yu Wanhong. On how to establish a construction enterprise comprehensive budget management system[J]. Heilongjiang Science and technology information, 2009 (20). 